\title{
Assessing the diversity of anti-establishment and populist politics in Central and Eastern Europe
}

\author{
Engler, Sarah ; Pytlas, Bartek ; Deegan-Krause, Kevin
}

\begin{abstract}
The more populism enters public debates, the more it needs close scrutiny. Central and Eastern Europe offers a useful context for exploring the diversity of parties identified as populist. Antiestablishment rhetoric provides a suitable conceptual starting point because of its pervasive role in the region's political discourse. Using a new expert survey, this article details the relationship between antiestablishment salience and political positions, showing that anti-establishment parties occupy a full range across both economic and cultural dimensions and many occupy more centrist positions. Narrowing the focus to content analysis of anti-establishment parties' thin ideology in the Czech Republic, Poland and Slovakia, it is concurrently found that for many actors (including those usually labelled as populist) antiestablishment rhetoric is indeed predominant, yet not always extensively combined with other elements of populism: people-centrism and invocation of general will. The findings are important for understanding multiple varieties of anti-establishment politics also beyond the region.
\end{abstract}

DOI: https://doi.org/10.1080/01402382.2019.1596696

Posted at the Zurich Open Repository and Archive, University of Zurich

ZORA URL: https://doi.org/10.5167/uzh-177311

Journal Article

Accepted Version

Originally published at:

Engler, Sarah; Pytlas, Bartek; Deegan-Krause, Kevin (2019). Assessing the diversity of anti-establishment and populist politics in Central and Eastern Europe. West European Politics, 42(6):1310-1336.

DOI: https://doi.org/10.1080/01402382.2019.1596696 


\title{
Assessing the diversity of anti-establishment and populist politics in Central and Eastern Europe
}

\author{
Sarah Engler \\ Department of Political Science, University of Zurich; \\ Bartek Pytlas \\ Geschwister Scholl Institute of Political Science, LMU Munich \\ Kevin Deegan-Krause \\ Department of Political Science, Wayne State University
}

\section{Preprint}

Published as: Engler, Sarah; Pytlas, Bartek and Kevin Deegan-Krause (2019): 'Assessing the diversity of anti-establishment and populist politics in Central and Eastern Europe'. In: West European Politics. https://doi.org/10.1080/01402382.2019.1596696

\begin{abstract}
The more populism enters public debates, the more it needs close scrutiny. Central and Eastern Europe offers a useful context for exploring the diversity of parties identified as populist; antiestablishment rhetoric provides a suitable conceptual starting point because of its pervasive role in the region's political discourse. Using a new expert survey, this article details the relationship between anti-establishment salience and political positions, showing that anti-establishment parties occupy a full range across both economic and cultural dimensions and many occupy more centrist positions. Narrowing the focus to content analysis of anti-establishment parties' thin ideology in the Czech Republic, Poland, and Slovakia, we concurrently find that for many actors (including those usually labelled as populist) anti-establishment rhetoric is indeed predominant, yet not always extensively combined with other elements of populism: peoplecentrism and invocation of general will. The findings are important for understanding multiple varieties of anti-establishment politics also beyond the region.
\end{abstract}

\section{Keywords}

Political parties; populist; anti-establishment; Central and Eastern Europe; left and right 


\section{Introduction}

Cases from Central and Eastern Europe demonstrate systemic patterns that can enrich the broader understanding of populist politics as it is practiced in contemporary democracies. Central and Eastern Europe (CEE, which for the purposes of this paper includes the 11 states on the eastern edge of the EU with histories of communist rule) is home to a number of political parties that link populism's 'thin ideology'- the expression of the general will of a homogenously virtuous people in opposition to homogenously corrupt elite (Mudde 2004) with other ideologies across a broader political spectrum. Several studies suggest that alongside the usual suspects on the radical right (Mudde 2007; Minkenberg 2015; Pytlas 2015; Pirro 2015) and the radical left (March 2007; March and Keith 2016), populist politics in CEE includes parties sometimes termed 'centrist populists' (Učeň 2007; Pop-Eleches 2010) that belong to neither of these categories. The region is also home to parties that adopt only some of the elements related to populism while leaving others behind, resulting in broad anti-establishment discourse in the region which includes not only populism but also technocracy, clientelism and other modes of challenging the existing political elite (Sikk 2009; Hanley and Sikk 2016). An analysis of CEE makes visible the discursive varieties of anti-establishment politics, including populist political communication (Jagers and Walgrave 2007; Hawkins 2009) and highlights the degree to which different actors combine anti-establishment rhetoric with other key elements of populism - people-centrism (Rooduijn and Pauwels 2011) and the notion of general will (March 2017) - within their 'thin ideological' discourse.

Central and Eastern European cases offer extensive raw material for studying antiestablishment politics in general and populist politics in particular. Throughout the region, patterns of political instability related to the rise of anti-establishment actors are more than just electoral 'earthquakes'. They seem instead to be a long-term, system-wide phenomenon brought about by constantly (re-)emerging new challengers to more-or-less established parties. The effect in some cases was a creation of a sub-party system of 'self-sustaining, cyclical' anti- 
establishment supply (Haughton and Deegan-Krause 2015: 68). Contemporary scholarship suggests several contextual explanations for changes in support of anti-establishment parties (including populist ones) including economic and political crises, corruption (real and perceived), as well as the instability of party systems (Kriesi and Pappas 2015; Engler 2016; Hanley and Sikk 2016). Overall, however, these studies reveal a complex relationship between particular conditions and populist success that is at best 'fuzzy' (Kriesi and Pappas 2015).

Explanations for the growth of anti-establishment politics are also difficult to establish with precision in Central and Eastern Europe because both crises and the anti-establishment parties have been present from the beginning of democratization. Whereas the 2008 economic crisis in Western Europe initiated a period of relatively high unemployment, austerity policies, personal and systemic financial uncertainty, and increased distrust in political leaders that might explain political change, all of these symptoms were already old news to the inhabitants of Central and Eastern Europe who had experienced them on and off for nearly two decades (Kornai 2006). Likewise, the region was long accustomed to politicization of socio-cultural conflicts, mainstream diffusion of radical right threat narratives against ethnic and social minorities, and framing contests over collective identity issues in midst of mainstream party competition (Pytlas 2015) by ambitious political entrepreneurs who already had significant practice in the art of 'performing crisis' (Moffitt 2016: 9). External events may have propelled some changes, but the region already was rich in active political agents who had already learned how to pull those triggers as part of their anti-establishment political initiatives. Observing the many programmatic and discursive varieties of populist political agency in Central and Eastern Europe can therefore provide us with crucial lessons on patterns that are increasingly gaining relevance for party systems in the West and elsewhere around the world.

This article explores the varieties of anti-establishment and specifically populist politics in Central and Eastern Europe from both a programmatic and a discursive perspective. It analyses how parties combine the anti-establishment element of populism with characteristics 
of thicker ideological streams, and how the internal elements of populism are themselves combined with one another in varying degrees and combinations. Our motivation is both conceptual-analytical and empirical. First, instead of contrasting populism as a 'thin ideology' with populism as 'discourse,' we instead underscore their complementarity as multiple dimensions that can find creative and versatile application in the hands of populist political agency. Second, as there have been few systematic comparative tests of assumptions about multiple varieties of populism in CEE, we analyse them empirically by triangulating quantitative and qualitative analysis. Given the aforementioned conceptual premises of extant research, we begin with the broad category of anti-establishment politics in general, analyzing the patterns of combination between this key 'thin' feature of populism and different 'thick' ideological positions not only on the radical left and right, but also in a variety of spaces often identified as the 'centre'. We empirically test previous claims of left-centre-right programmatic variety (Učen 2007) by looking at the distribution of anti-establishment parties in the ideological space across the region, combining a new expert survey on parties' use of antiestablishment rhetoric in parliamentary electoral campaigns (Engler et al. forthcoming) with the Chapel Hill expert survey on party positions (Bakker et al. 2015a, 2015b). In the second part of the paper we narrow the extension and widen the intension of the observed phenomena (Sartori 1970) with an in-depth analysis of the degree to which anti-establishment parties combine the three narrative building blocks of populism. For this purpose, we focus on all major anti-establishment actors in Poland, Slovakia, and the Czech Republic and conduct a ComputerAssisted Qualitative Content Analysis of their social media electoral campaign discourse.

Overall, we find not only that anti-establishment parties occupy a wide variety of positions on the ideologically 'thick' dimensions of culture and economics, but also that they exhibit considerable variation in constellations of narrative elements that are associated with 'thin' ideology of populism. Our analysis provides comparative empirical evidence that in Central and Eastern Europe, anti-establishment rhetoric can be found across the ideological 
spectrum (including the centre) and constitutes a predominant discursive building block of these actors' 'thin ideological' supply. At the same time, anti-establishment claims are not necessarily linked to other key elements of populist discourse such as people-centrism or, most notably, the general will.

\section{Anti-establishment politics in the ideological landscape of Central and Eastern Europe}

Before looking deeper into the more complex elements of populism, it is useful to begin with the category of anti-establishment politics which exhibits fewer dimensions and includes a larger number of cases. Expert survey data shows that anti-establishment politics has distinct contours within the party systems of the region and that some of these patterns run counter to expectations.

By combining data from a new expert survey that measures the salience of anti-elite and anti-establishment rhetoric (Engler et al. forthcoming) with data from the Chapel Hill expert survey (Bakker et al. 2015) it is possible to explore how the use of anti-establishment rhetoric is distributed among Central and Eastern European parties of different ideological camps. The new expert survey, conducted in Winter 2015/2016, asked experts to indicate the salience of anti-elite and anti-establishment rhetoric ${ }^{1}$ of political parties in their electoral campaign on a scale from 0 (not important at all) to 10 (extremely important). The dataset fully covers all national parliamentary campaigns of all political parties between 2009 and 2016 in the $11 \mathrm{EU}$ member states of Central and Eastern Europe. ${ }^{2}$ In total, 122 experts (11.1 experts per country; from 5 experts in Latvia to 18 experts in the Czech Republic) participated in the survey. The complementary Chapel Hill expert survey measures expert assessments of party positions on a unidimensional left-right scale (lrscale) and in a two-dimensional ideological space with an economic (lrecon) and a cultural dimension (galtan). A combination of the two datasets allows for a comparison of the ideological positions with the anti-establishment rhetoric of political parties between 2009 and $2014 .^{3}$ 
Figure 1 provides the overall distribution of party positions on four questions and shows a wide distribution of locations on the anti-establishment position (with a peak at near the lower end of the distribution) and a roughly symmetrical, centre-peak distribution of positions on the general, economic and cultural left-right question (where GAL stands for Green/Alternative/Libertarian approximating the cultural left and TAN stands for Traditional/Authoritarian/Nationalist approximating the cultural right).

Figure 1. Distribution of individual party positions on anti-establishment and left-right axes for political parties in Central and Eastern Europe, 2009-2014.

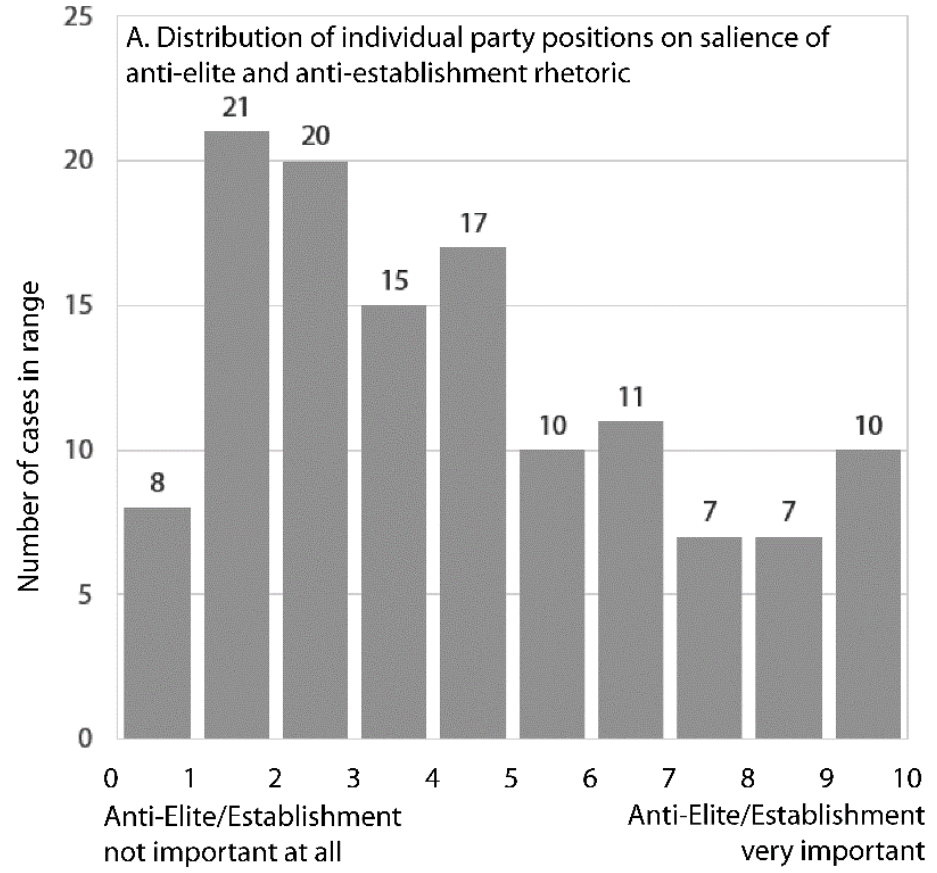

B. Distribution of individual party positions on general left-right position

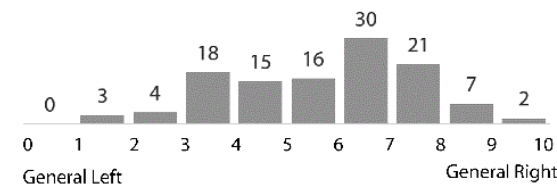

C. Distribution of individual party positions on economic left-right position

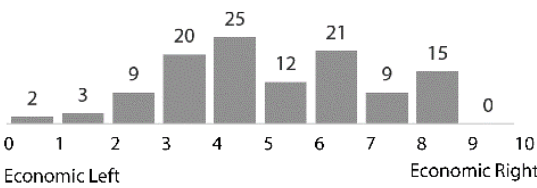

D. Distribution of individual party positions on cultural left-right (GAL-TAN) position

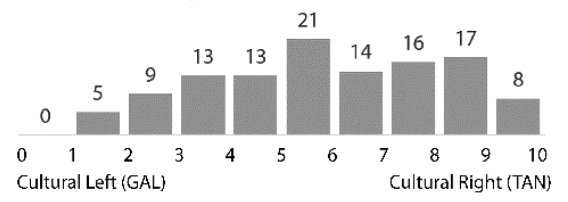

Source: Engler et al. forthcoming; Bakker et al. 2015a, b.

Figure 2 looks at the use of anti-establishment rhetoric of all major parties in all CEE elections between 2009 and 2014 according to the parties' left-right orientations. Since levels of anti-establishment rhetoric differ from country-to-country, Figure 2 also uses dark, circular 
markers to identify those parties that are above average compared to other parties in individual national party systems. The figure clearly shows a high diversity of orientation among those parties categorised by the experts as giving more salience to anti-establishment rhetoric than average for a given election (and for brevity we refer to those here as 'anti-establishment parties' or AEPs, though it is important to note that the classification relates to parties in particular elections rather than for their entire existence). We find such parties on the far left, on the far right, and everywhere in between. There is no correlation between the salience of anti-establishment rhetoric and the position on a left-right scale ( $\mathrm{r}=.017)$. The lack of linear correlation along the left-right axis, however, fails to address the T-shaped pattern of cases that is visible in the scattergram which shows that anti-establishment parties range from far left to far right (1.0 to 9.7 on the 11-point scale), but parties with lower use of anti-establishment claims occupy a much narrower range (2.7 to 8.3 on the same scale). Many parties follow the predictions of the literature on populism by combining anti-establishment rhetoric with thick ideologies on the far left and far right. A striking finding, however, is the high number of AEPs that are not located in the ideological extremes, and ideologically fit neither into the category of the radical right nor of the radical left.

Some of the apparent centrism is the result of the common but inadequate method of categorising parties along a single left-right dimension. A single dimension makes it difficult to place parties such as Bulgaria's xenophobic, but economically leftist party Attack (Ataka). It is therefore necessary to take a closer look at the distribution of the party positions on the two main dimensions of political competition: an economic dimension defined in terms of left versus right, and a cultural dimension defined in terms of GAL and TAN. 
Figure 2. The salience of anti-establishment rhetoric by political parties in Central and Eastern Europe by position on the general left-right dimension

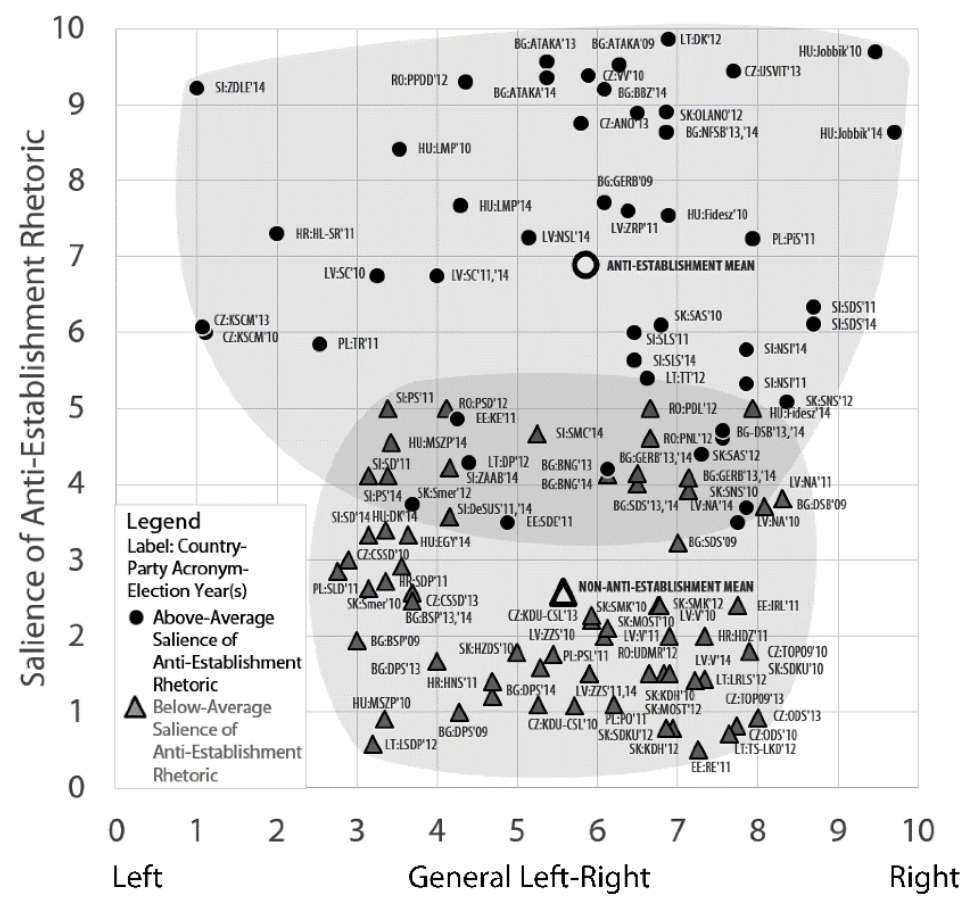

Note: Because the threshold for "above average" and "below average" salience is based on the average for the five strongest parties in each individual election it is possible for the same raw salience score to fall in the above- or below-average categories depending on the overall salience in the election itself.

Source: Engler et al. forthcoming; Bakker et al. 2015a, b.

Figures $3 \mathrm{a}$ and $3 \mathrm{~b}$ compare the distribution across the economic and cultural dimensions of parties with above-average and below-average salience of anti-establishment rhetoric. These figures suggest that the above-average parties, which we refer to as anti-establishment parties (AEPs), are more likely to be found on the centre-left on economic questions and on the traditionalist/authoritarian side of cultural questions, but to assess the full picture, we must put both dimensions together. 
Figure 3. Distribution (density curve) of anti-establishment parties and non-antiestablishment parties over the economic and cultural dimensions
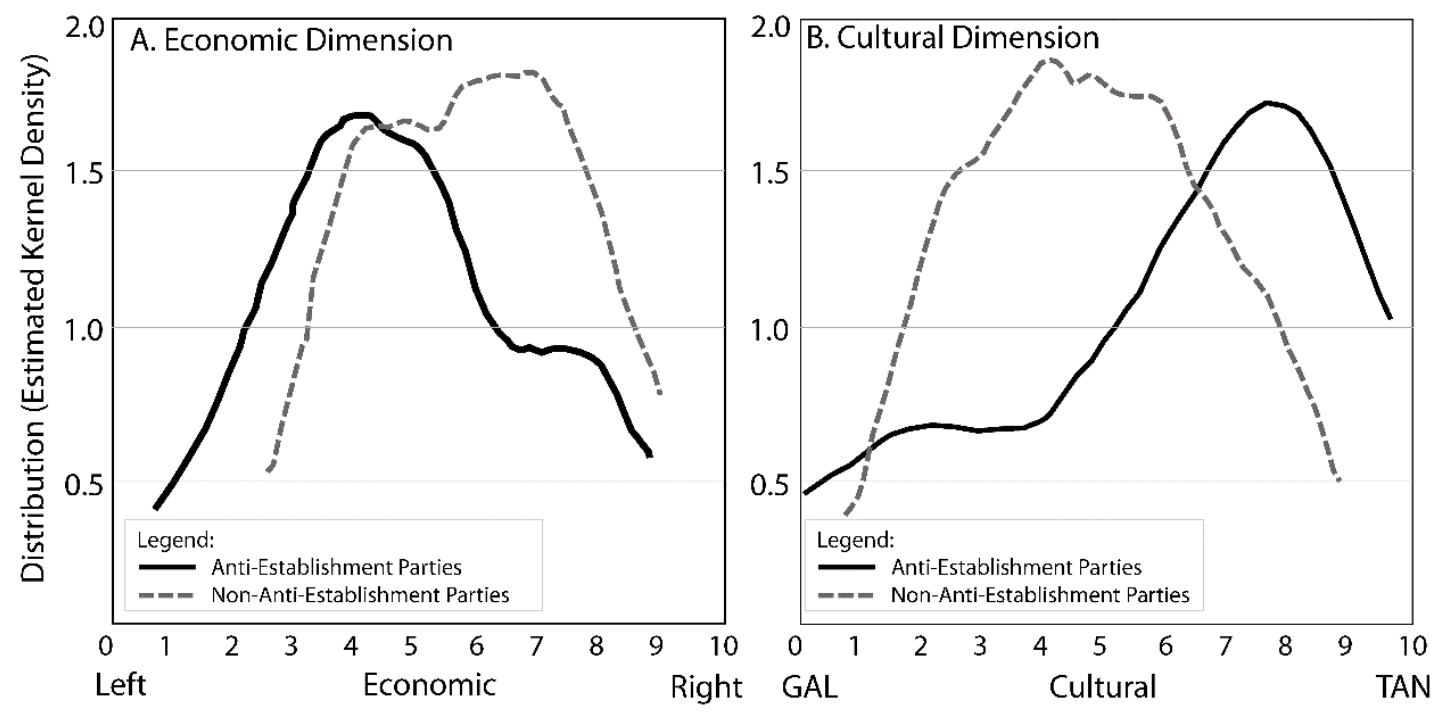

Note: Anti-Establishment Party: above average salience of anti-establishment rhetoric; NonAnti-Establishment Party: below average salience of anti-establishment rhetoric

Source: Engler et al. forthcoming; Bakker et al. 2015a, b.

Figure 4a illustrates the ideological distribution of AEPs while $4 \mathrm{~b}$ shows the distribution of non-AEPs. ${ }^{4}$ The difference in patterns clarifies the pattern in Figures 2 and 3: Non-AEPs are generally located closer to the centre and only rarely take positions that are close to the end of one or both dimensions. AEPs have a relatively similar mean (especially on economic questions) but are far more widely spread across both dimensions of the graph. Some fall near the far-left pole of the economic dimension, such as the Communist Party of Bohemia and Moravia (KSČM) and the Slovenian Unified Left (ZDLE), while others fall near the TAN pole 
of the cultural dimension that is usually associated with the radical right such as Bulgaria's Ataka, the Movement for a Better Hungary (commonly known as Jobbik), or the Slovak National Party (SNS). A large number of AEPs, however, occupy the same ideological space as their non-AEPs counterparts while others represent positions far from those associated either with the cultural-driven definition of the populist radical right or the economic-driven definition of the populist radical left, such as Poland's culturally left Your Movement (TR) or Slovakia's pro-market Freedom and Solidarity $(\mathrm{SaS}) .^{5}$ This finding also corresponds with emerging literature that claims that many of the successful anti-establishment parties in Central and Eastern Europe, including populist ones, are located within the ideological mainstream ${ }^{6}$ (Učeň 2007; Pop-Eleches 2010; Hanley and Sikk, 2016). Commonly cited examples of centrist AEPs include the Czech Republic's Alliance of Dissatisfied Citizens (ANO) or Lithuania's National Resurrection Party (TPP) with no clear ideological platform, and also include parties such as the moderate-left Politics Can Be Better (LMP) in Hungary, or the centre-right Citizens for the European Development of Bulgaria (GERB). ${ }^{7}$

Moreover, other parties with strong anti-establishment views fall clearly into space often associated with populism, but do so in a way that undermines attempts at a binary distinction between inclusionary and exclusionary populism. On the socio-cultural dimension, some parties that take an exclusionary, traditionalist-nationalist stance seek supporters through redistributive economic policies as long as they benefit only the 'in-group' (cf. Mudde and Rovira Kaltwasser 2013). This combination of left-wing economic policies and authoritarian/nativist stances appears to be more widespread in Central and Eastern Europe than in the West but seems to be expanding its geographic reach (see Kitschelt 1992; Marks et al. 2006; Rohrschneider and Whitefield 2009). Parties with this ideological profile occupy a wide range on the unidimensional left-right spectrum in Figure 2, including the social-conservative right such as Poland's Law and Justice (PiS), the Hungarian Fidesz (Vachudova 2008; Pytlas 2015), nationalist communists (such as the Bulgarian BSP or the Czech KSČM), and even 
mainstream left parties such as Direction (Smer) in Slovakia or Romania's Social Democratic Party (PSD) (cf. Pop-Eleches 2008; Pytlas 2013). These mixed cases along with the AEPs that are moderate on both dimensions illustrate the need to approach inclusionary and exclusionary populism carefully, treating them not as rigid, exclusive categories but as positions on two dimensions of a multidimensional frame (cf. Mudde and Rovira Kaltwasser 2013) that in practice are often subject to stretching and blurring.

Figure 4. The distribution of anti-establishment parties and non-anti-establishment parties in the two-dimensional space of party competition in Central and Eastern Europe (economic left/right, GAL-TAN)
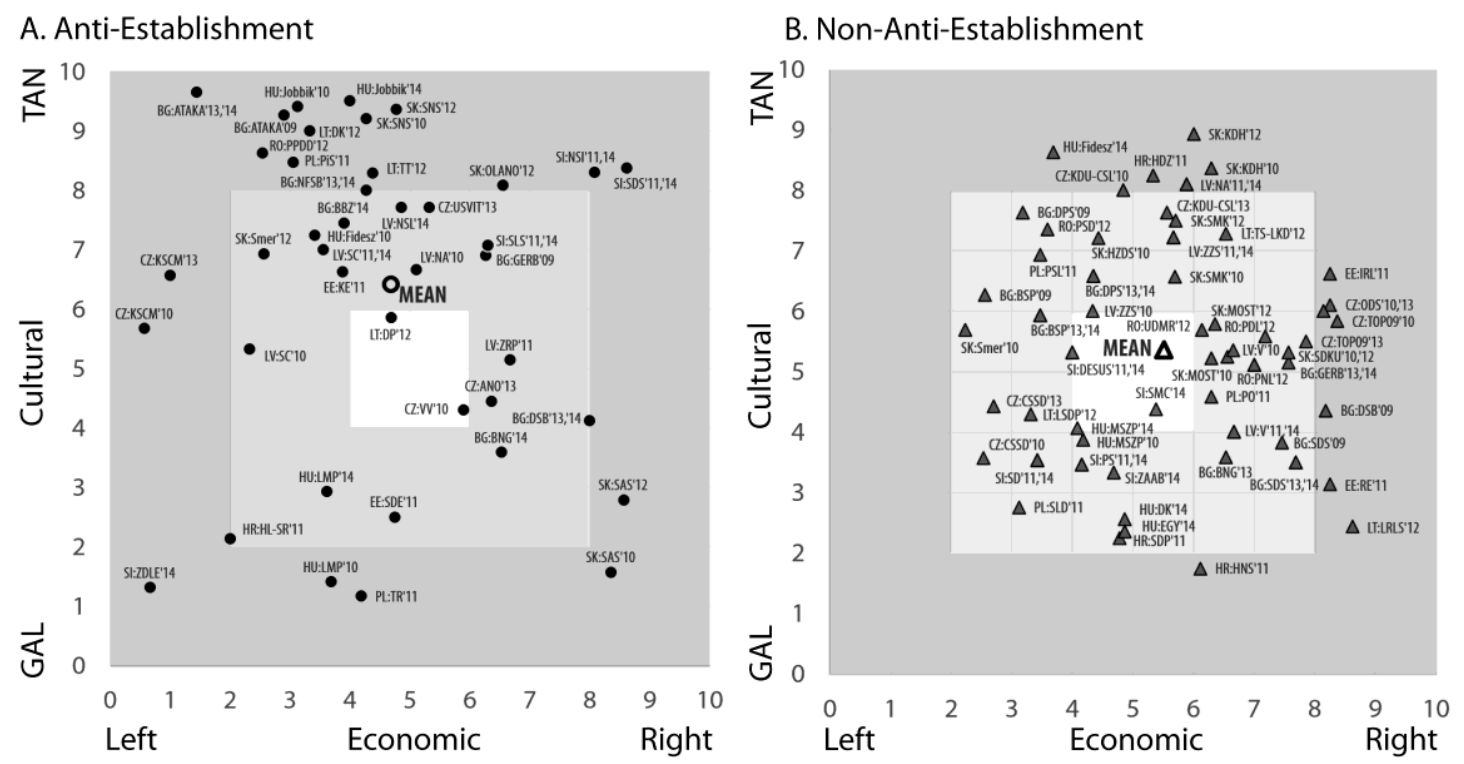

Note: Anti-Establishment Party: above average salience of anti-establishment rhetoric; NonAnti-Establishment Party: below average salience of anti-establishment rhetoric.

Source: Engler et al. forthcoming; Bakker et al. 2015a, b.

The multifaceted nature of the dimensions and particularly, the complexity of the definitions behind those concepts (not to mention the problem of choosing a clear threshold 
between radical and non-radical) suggest caution in assigning these categories to particular parties, but the evidence clearly suggests that in Central and Eastern Europe, anti-establishment rhetoric extends far beyond categories of the populist radical right and left originally derived from research on Western European democracies.

\section{Anti-establishment politics and the extent of populism in Central and Eastern Europe}

Our evidence confirms that anti-establishment politics in Central and Eastern Europe has multiple faces and is not a phenomenon constrained to the ideological extremes or to one ideological camp. While this is a valuable insight in itself, it points to the need for a deeper exploration of patterns of anti-establishment discourse particularly its combination with other building blocks of populism. Observing the extent to which anti-establishment actors are populist (if at all) is important not only in the cases of the radical right and radical left (Mudde 2007; Rydgren 2017; March and Keith 2016), but also for less-studied parties nearer the centre that also lean heavily on their opposition to the establishment. While some scholars refer to non-radical anti-establishment parties in CEE exclusively as 'centrist populists' (Učeň 2007; Pop-Eleches 2010), others argue that not all of these actors are in fact populist, instead describing such cases as 'anti-establishment reform parties' (Sikk 2009; Hanley and Sikk 2016). A more systematic empirical test of these categorizations requires a closer look into party discourses deployed by anti-establishment political entrepreneurs from the left, centre, and right in CEE.

This step of our analysis is informed by several extant discourse-analytical attempts to assess elements of populism (see Deegan-Krause and Haughton 2009; Hawkins 2009; Roodujin and Pauwels 2011; Caiani and Graziano 2016; March 2017) that employ the understanding of populism as a 'thin ideology' (Canovan 2002; Mudde 2004). In line with Mudde (2004), populist discourse can be seen as a combination of three elements: general people-centrism, general anti-establishment rhetoric, and a claim that politics should express a monist volonté 
générale. A measurement of appeals to general will is nevertheless not always isolated in previous studies that empirically identify populism only as a combination of anti-elitism with people-centrism (e.g. Jagers and Walgrave 2007; Roodujin and Pauwels 2011). We therefore agree with March (2017) that it is crucial to account for all three discursive elements of populist discourse, both for reasons of conceptual scrutiny and empirical clearness. Identifying general people-centrism allows it to be separated from specific class-based discourse. Measuring the prominence of general anti-establishment claims helps to identify 'merely' demotic discourse, i.e. non-antagonist rhetoric of closeness to a homogenous 'people' (cf. March 2017). In turn, accounting for invocations of general will allows to better distinguish specifically populist discourses from solely technocratic (Caramani 2017), as well as 'merely' demotic or clientelist rhetoric that can also be articulated by non-populists (Mudde 2004; Mudde and Rovira Kaltwasser 2017; March 2017). Capturing this narrative diversity requires close attention to a large number of statements from each party. It is therefore necessary to use a restricted but representative subset of the cases above.

The following section relies on a content analysis of social media discourse of significant anti-establishment parties during recent parliamentary election campaigns in the Czech Republic (2013), Poland (2015), and Slovakia (2016). The case selection method follows Roodujin and Pauwels (2011) and includes cases that allow observation of the broad variety of anti-establishment politics across ideological positions while not differing significantly from the region as a whole. Although the three countries under scrutiny occupy a compact geographic space within the overall sample, they are nevertheless broadly representative of the region's parties: the overall average position of these countries' parties on the economic left-right, GAL-TAN, and anti-establishment measures is statistically indistinguishable from the other countries in the region and the standard deviations of party positions are also extremely similar between the sample and the whole region. Within the three selected countries, the sample of parties chosen for the content analysis consists of political actors that in the latest election 
gained parliamentary representation or received at least 3 per cent of vote and were attributed with an above-average salience of anti-establishment rhetoric (salience above country mean, see Table A1 in the Appendix). ${ }^{8}$ In two cases in Poland continuity issues with party social media made it preferable to analyse the social media content of the party leaders: Robert Winnicki of RN and Janusz Korwin-Mikke of the Coalition for the Renewal of the Republic-Liberty and Hope (KORWiN). ${ }^{9}$

Our measurement of claims related to populist discourse proceeds by means of ruleguided Computer-Assisted Qualitative Data Analysis (CAQDA) (Kuckartz 2007), a technique previously applied to empirical analysis of radical right politics in the region (Pytlas 2015). The CAQDA follows general principles of rule-guided qualitative content analysis (Mayring 2000), in that the core non-automated, interpretative coding procedure is systematically controlled by clearly operationalised, theory-based analytical categories. The advantage of rule-guided CAQDA is that it allows us to strike a balance between nuanced, hermeneutic identification of narrative patterns within party supply and a systematic quantifiable comparative analysis (cf. Pytlas 2015) that helps to account for contextual and tactical variety of anti-establishment supply both within and across ideological positions. A fine-grained content analysis that 'takes populism apart' (Deegan-Krause and Haughton 2009) by disaggregating its particular discursive building blocks furthermore allows to isolate the anti-establishment character of party supply that is not necessarily people-centrist or does not invoke to follow a uniform volonté générale.

Our analytical categories follow the ideational definition of populism by Mudde (2004). We account for articulated fundamental division between 'the People' and 'the Elite', as well as arguments that politics should express a uniform 'general will'. Anti-establishment rhetoric is operationalised through a challenge to 'established politics' or 'elites' in their homogenous or pars pro toto portrayal (cf. March 2017), such as 'standard parties', 'mainstream media', or 'big capital'. We exclude references to particular groups or institutions such as a specific party, 
newspaper, or bank unless these were rhetorically exhibited as systemic representatives of antagonistic 'established politics' or 'elite'. This allows to better control for contextual variety and tactical blurring while still clearly distinguishing general anti-establishment rhetoric from specific anti-incumbent or anti-elitist claims.

People-centrist statements describe claims that positively refer to a homogenous 'people'. They also include references to related notions that imply a collective character of the people, such as 'the citizens', 'the sovereign', or 'the nation'. This category excludes diffuse appeals to 'us' or 'you' where the subject is not clearly distinguishable, as well as, again, claims that reference a sub-group of the population such as 'workers' or 'young people', except where these represent the entirety such as 'all families', or 'common people' (cf. March 2017).

Invocations of general will are operationalised by positive references to popular sovereignty in its monist and majoritarian interpretation, including appeals to popular control and demands for referendums. Following March (2017), these claims were distinguished from people-centrism and coded as general will only if the reference to 'the people' had an actionoriented normative emphasis, such as 'our politics is guided by what the people want'. If the claim accentuated problems of 'the people', but was not action-oriented (such as 'the common people are struggling every day'), it was instead coded as people-centrism.

The textual corpus selected to identify these categories consists of public Facebook status posts of the selected actors gathered for a narrow time period around the election (three months prior and one week following). The choice of medium reflects the role of social media as one of key channels of political communication for radical parties and anti-establishment challengers (see Caiani and Parenti 2013; Gerbaudo 2014; Aalberg et al. 2016 among many others). Social media campaigning is crucial especially for newly founded anti-establishment parties that lack organizational resources such as a press office, as well as those that (whether for political or organizational reasons) draft only rudimentary party manifestos prior to the election. The analysis of official social media outlets, most particularly Facebook fan pages, 
furthermore captures a 'political conversation about a party that is actually under the control of the party' (Arzheimer 2015: 548, italics in original). It thus fulfils similar functions to press releases: presenting 'a picture of party-refined and party-desired impact on public opinion' (Pytlas 2015: 92) thereby is better than the more static positions of party manifestos at capturing a fine-grained and dynamic picture of various patterns and adjustments of discursive strategies deployed by anti-establishment challengers in the course of the campaign. The coding unit is a quasi-sentence (Budge et al. 2001; Kleinnijenhuis and Pennings 2001). A quasi-sentence is 'an argument or phrase which is the verbal expression of one idea or meaning' (Klingemann et al. 2006: xxiii). As shown by March (2017), coding quasi-sentences allows to draw a more nuanced picture of articulated claims. All quasi-sentences not attributed to any discursive element of populism were coded into a separate category to allow comparison between anti-establishment, people-centrism, and invocations of general will relative to all statements during a particular electoral campaign.

The analysis demonstrates the wide diversity of anti-establishment politics in the Czech Republic, Poland, and Slovakia. The picture of this manifold variety emerges already from a first descriptive look on the extent to which particular actors deployed elements of populism in their electoral campaigns. As Figure 5 demonstrates, particular anti-establishment actors varied in the intensity to which they legitimized their supply with 'thin' building blocks of populism. Of the analysed parties, claims related to populism constitute a considerable part of political supply especially for the Slovak Ordinary People and Independents (OLaNO) and People's Party Our Slovakia (LSNS), as well as the Czech Republic's Dawn of Direct Democracy Tomio Okamura (Úsvit) and the movement of Paweł Kukiz (Kukiz) in Poland. On the other hand, for some primarily anti-establishment actors such as KORWiN in Poland, ANO in the Czech Republic, and SaS in Slovakia, the usage of other claims related to populist rhetoric in their election campaigns is minimal. Particular actors differed significantly in the extent to which 
they used and combined the particular elements of populism within their 'thin ideological' discourse.

Figure 5. Elements of populism as a share of all social media campaign claims in antiestablishment parties of Central and Eastern Europe.

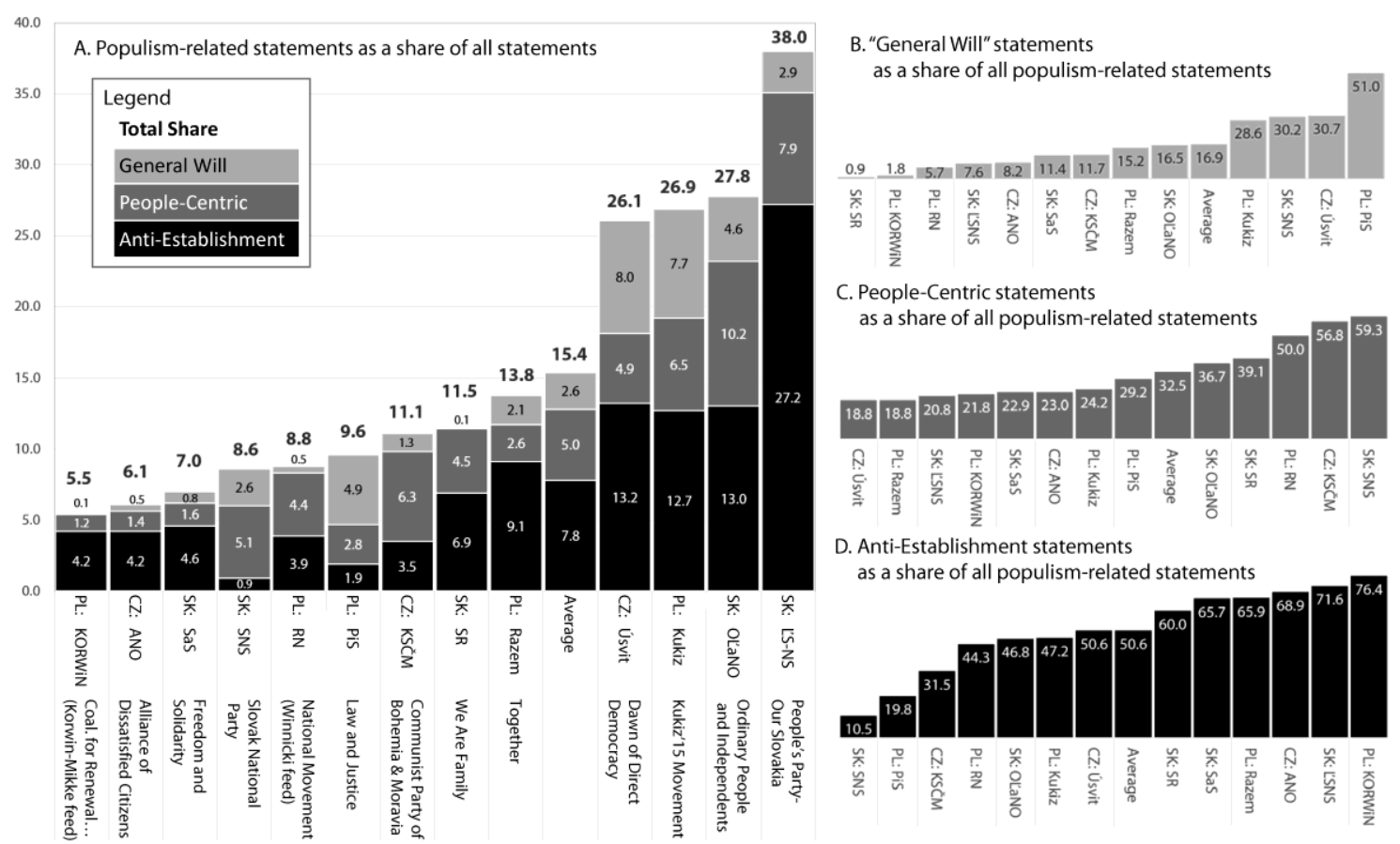

Source: Pytlas forthcoming.

As Figure 5 shows, for the majority of the cases under study, the general antiestablishment rhetoric formed the largest share of their populism-related discourse, but there is significant diversity even within the ideological camps. Of the economically left-wing antiestablishment parties, the Czech KSČM puts much less focus on challenging 'the elite' than the newly-emergent Polish party Razem which adopted a general 'anti-partyism' platform comparable to Spain's We Can (Podemos). Anti-establishment claims also tended to dominate among more economically and culturally centrist parties. Of these only the Slovak OL'aNO 
(whose position on any dimension is hard to define) exhibited a significant share of other populism-related claims to supplement its anti-establishment positions. Among parties on the right, the overall patterns also differed. A relatively even distribution of categories (like that of OLaNO) appeared in the statements of Úsvit in the Czech Republic, and in those of Kukiz in Poland whose main anti-establishment thrust was directed against what the party leader described as a detached and tribalistic 'party-cracy' (e.g. Kukiz 29.07.2015). For several actors with a TAN orientation associated with the 'radical right' - especially the LSNS and KORWiN - anti-establishment rhetoric constituted the predominant narrative within the 'thin ideological' discourse. This confirms our findings that although anti-establishment appeals are somewhat more likely toward the TAN-pole of the cultural spectrum, they can be found across the ideological space.

In the more established parties on the right - SNS in Slovakia and PiS in Poland - attacks on the homogenous 'elite' played a smaller role than other core elements of populism, in part because these parties focused on a specific rival rather than employing a general antiestablishment campaign. The SNS under the new leadership of Andrej Danko strategically moderated its supply of general anti-establishment rhetoric and instead focused its ire against a relatively close competitor, the Christian Democratic Movement, and against an easy target, the party Bridge (Most-Híd) which had strong ties in the Hungarian minority. In Poland, PiS targeted its traditional nemesis, the ruling Civic Platform (PO). During its electoral campaign of 2015, PiS also strategically toned down its radical rhetoric. During the electoral campaigns it framed its self-portrayal as a challenger force against the elites of 'liberal Poland' reified by the PO (cf. Szczerbiak 2007; Pytlas and Kossack 2015) through a moderated, specific antiincumbent rather than general anti-establishment lens.

These findings compel further exploration of other populist elements in the discourse of anti-establishment parties. Figure 5 suggests that relatively few parties focused on their appeals on a 'people' defined in homogenous terms. Differences within some ideological camps were 
again high. On the anti-establishment economic left, the predominantly demotist discourse of the authoritarian left KSČM in the Czech Republic was much more pronounced than that of the 'New Left' Razem that to a stronger extent articulated classical socialist interest-based politics focused on particular occupational groups. Anti-establishment parties on the economic right also tended to avoid people-centrism and instead made appeals to various societal groups rather than to a homogenous 'people.' ANO for example referred to employers, seniors, single parents, or (job-seeking) school graduates (cf. ANO 23.10.2013). On the cultural right the peoplecentred discourse was more common and appeared frequently in statements by parties such as SNS in Slovakia and Winnicki's RN in Poland, most often in the specific form of a homogenous 'nation' standing in for a homogenous 'people'. Other parties took different approaches. Slovakia's OLaNO constructed its anti-political agenda by pitting corrupt professional political class against non-political civic activism of a unitary collective actor made out of 'ordinary persons' while its competitor We Are Family (SR) founded by the businessman Boris Kollár used clientelist appeals both to a uniform 'People' and to specific groups (the youth, families). SR candidates frequently referenced the 'family' emphasis of the party's name but tended to frame its support for Slovak families mostly in socio-economic terms - 'We seek a radical change in Slovakia, a change for the better so that it could be a joy to live, work and start a family in Slovakia' (cf. Sme Rodina 08.02.2016) - rather than from traditional socio-cultural judgments about what constitutes a morally-appropriate family.

This picture becomes even more refined once references to volonté générale are brought into equation. On the left, Razem invoked participative, non-authoritarian calls for citizen empowerment and 'real' popular control of politics (Razem 13.08.2015). In the centre, OL'aNO presented itself as an expression of non-political civic activism. At the same time, several antiestablishment parties on the cultural right, such as Kukiz, SNS, Úsvit, and PiS, indeed put more focus on active expression of the homogenous 'will of the people' to augment their peoplecentrist and anti-establishment appeals. 
For the SNS, these appeals consisted of classical radical right claims to represent 'the national interest'. Other, newer parties such as the Czech Republic's Úsvit as well as the Poland's Kukiz demanded steps to enable direct political representation of a homogenous will of 'the people' while their other ideological positions remained fluid on the TAN borderline of the radical right. During their first parliamentary elections, they articulated nativist positions describing Islam as a threat to the nation state and Europe (cf. Okamura 24.10.2013; Kukiz'15 16.09.2015). Concurrently, their most salient issue and distinctive anti-systemic appeal rested in presenting themselves as champions of direct democracy and citizen activation (cf. Okamura 25.10.2013; Kukiz 29.07.2015). After Okamura left Úsvit in 2015 because of severe internal conflict he went on to create a new party, Freedom and Direct Democracy (SPD) built on an ideological foundation of overt nativism directed against Islam. SPD won 10.6 per cent of vote in the 2017 election, marking a political consolidation of Okamura's radical right profile. It remains to be seen whether Kukiz, whose electoral lists and parliamentary caucus included persons who belonged to or were endorsed by the extreme right Ruch Narodowy (RN), will follow in Okamura's footsteps. In relative numbers, the party with the most common references to the 'will of the People' was Poland's PiS. After taking power in 2015, the party dropped more moderate aspects of its self-presentation, in favour of further pursuit of what it sees as a homogenous volonté générale. Claims to politically embody and express the 'general will' quickly became the main exculpation for government policies leading to the dismantlement of constitutional checks and balances (Pytlas 2018).

On the other hand, as Figure 5 further demonstrates, references to volonté générale during their electoral campaigns were marginal for most other anti-establishment parties. For RN and the LSNS, the frequent references to a homogenous 'Nation' rarely translated into the invocation of the 'will of the people'. The discourse of Janusz Korwin-Mikke also avoided references to general will. The reluctance in his case resulted from his elitist and antidemocratic ideology fueled by monarchism and extreme libertarianism that led him to self- 
censor all words referring to the demos (e.g. 'd***cracy', Korwin-Mikke 2012). Slovakia's SaS on the other hand engaged much more in laissez-faire interest-based politics than a claim to represent the will of the people. While Slovakia's SR vowed to help families in need (cf. Sme Rodina 23.02.2016), it did not bind itself to following a homogenous volonté générale. Finally, the Czech ANO of billionaire Andrej Babiš who emerged victorious from the Czech election campaign in 2017 with 29.6 per cent of votes represents a technocratic rather than populist variant of anti-establishment politics. In the 2013 campaign Babiš argued that he is not a politician, but a manager, and that in order to fix the functioning of the state, the Czech Republic needs someone who could run it just like a company (Kopeček 2016). Babiš tended to portray himself as an amicable philanthropic manager who knows how to care for those in his charge (whether employees or citizens) (cf. ANO 23.09.2013), rather than as a populist tribunus plebis.

The summary graph in Figure 6 shows the positions of all parties in this section on all three aspects of populism in a common space. Although all of these parties were classified by the expert survey as anti-establishment parties, the cluster near the upper anti-establishment angle shows the degree to which, for many parties, anti-establishment rhetoric is really the only significant populist element, leaving little room for references to the general will or the people. Actors that come closest to a populist discourse, where all elements of this 'thin ideology' were both balanced and used extensively are Kukiz, Úsvit, and OL'aNO. These parties focus explicitly on the question of general will, which in all three cases involves a call for more popular control of government and use of referendums to determine policy. The three oldest parties in the sample show the least attraction to the anti-establishment argument during their electoral campaigns, but subsequently differ on whether to emphasize the general will (PiS) or solely people-centrism, and in the case of the latter to focus on class (KSČM) or ethnicity (SNS). In Poland Winnicki's extreme right RN emphasized the people (defined in national terms) almost to the same degree as SNS but with more rejection of the establishment and less emphasis on the general will. For some parties, anti-establishment appeals were the only 
identifiable element of populism in absolute terms, and even here the challenge to 'the corrupt elite' differed widely between the extreme elitist Korwin-Mikke, the centrist laissez-faire SaS, and the technocratic ANO.

Figure 6. Relative frequency of three populism-related reference categories in antiestablishment parties of Central and Eastern Europe.

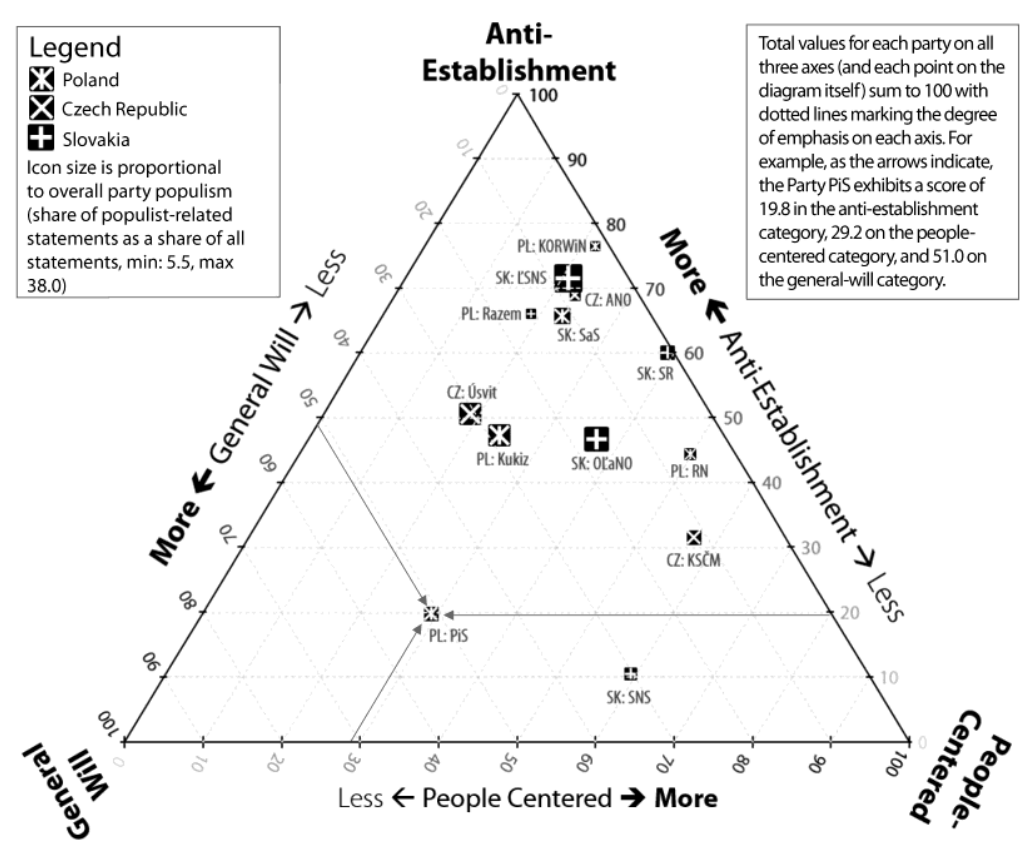

Source: Pytlas forthcoming.

Central and Eastern Europe thus reveals a significant variety of anti-establishment politics not only across and within left, centre, and right ideological positions, but also beyond populism. Most especially, the content analysis provides systematic empirical confirmation of the assumption by Hanley and Sikk (2016): not all centrist anti-establishment parties in CEE are populist - at least with regard to their recent electoral campaign discourse on social media. It is advisable to be cautious about assigning specific categories to political parties because of the inherently dynamic and blurring character of political discourses and extent to which the 
electoral context and tactics of political actors cause them to select different elements of populism (see the case of PiS), but our qualitative approach helps to control for these factors while retaining conceptual clarity. The evidence corroborates and expands upon the conceptual findings of March's case study of the UK (2017). The larger set of anti-establishment cases available in CEE demonstrates importance of analytically isolating the general will aspect of populism when compared to approaches that measure populism solely as the combination of anti-elitist appeals and general people-centrism (cf. Jagers and Walgrave 2007; Roodujin and Pauwels 2011). Not only does it allow for a sharper distinction between populist and 'merely' demotic claims (March 2017), but also between populist and 'merely' anti-establishment rhetoric.

While a case can sometimes be made for the use of 'diminished subtypes' of a particular phenomenon, this is less warranted with concepts such as populism that are already contested and fraught with disagreement. Concepts such as 'thin populism' or 'anti-elitist populism' (Jagers and Walgrave 2007) may confuse rather than enlighten because they simply omit one or more of the concept's necessary elements (March 2017), and because there is a wide range of acceptable alternatives that are more precise and do not obscure critical distinctions between populist and non-populist discourses. According to March, "what passes for (...) "thin" populism is not really populism at all but demoticism (closeness to ordinary people), which is necessary but by no means sufficient for populism. Therefore, analysts should not call parties “rather populist" just because their rhetoric is demotic' (March 2017: 3). As we demonstrate, this conceptual point is valid not only with regard to non-antagonistic people-centrism but also for anti-establishment claims. Rhetoric that is anti-establishment can be easily deployed in technocratic and even clientelist political strategies, and it is only with the addition of both a homogenous vision of 'the people' and a willingness to countenance a 'general will' that it rises to the level of populism. The tendency to see the victory of populism in the success of every 
party opposed to the establishment makes it more difficult to understand the nuances of contemporary political shifts.

\section{Conclusion}

The many and varied political entrepreneurs who have challenged conventional politics in Central and Eastern Europe over the past two decades makes the region ideal for exploring the multiple varieties of anti-establishment politics from a programmatic and narrative perspective. For a deeper understanding of the character, dynamics and evolution of populism and antiestablishment politics more broadly, it is useful to look beyond Western Europe. Combining quantitative expert surveys of CEE with qualitative content analysis reveals important underlying patterns in the region and also illuminate recent developments in Western Europe and in the rest of the world as well.

In terms of programmatic distribution, we provide expert survey evidence that in CEE anti-establishment politics is not confined solely to populists on the cultural radical right and the economic radical left. Although anti-establishment challengers are more common at these extremes of the cultural and economic spectrums, there are almost as many anti-establishment parties that stand in the political centre or exhibit alternative combinations of extreme and moderate positions. Unlike the more-easily labelled 'exclusionary' or 'inclusionary' positions

of the Portuguese, Spanish, and Greek cases studied by Lisi et al. (2019), many of the CEE parties defy quick categorisation.

The wider framework needed to account for CEE cases has also broader cross-national implications, providing a better scheme for understanding other Western European cases, such as the findings by Mosca and Tronconi (2019) that Italy's Five Star Movement combines strong anti-establishment rhetoric, ambiguous statements and centrist voter preferences on other issues in a pattern closely akin to many parties in CEE. Furthermore, the article by Bernhard and Kriesi (2019), disaggregating populism into three sub-components akin to those used here and 
examining populism in relation to distinct types of left and right, sets the stage for a similar comprehensive analysis across major Western Europe party systems.

In terms of discursive variety, we offer empirical confirmation of suspicions that many parties labelled as populist because of their anti-establishment rhetoric are not necessarily very populist in other, fundamental ways (Hanley and Sikk 2016). In the subset of countries studied here, most anti-establishment actors placed relatively less emphasis on a homogenous people or on the invocation of the volonté générale. In some cases, due to the marginal role of these elements in the examined electoral discourse at the particular point in time, the 'thin' ideology of some parties cannot be qualified as populist even if assessed as a matter of degree. This is true not only of anti-establishment politicians who are also anti-democrats (such as Poland's Korwin-Mikke), but also of anti-establishment parties with a technocratic focus (such as the Czech ANO), or parties without any recognizable ideological profile (such as Slovakia's Sme Rodina). This study shows how much research is left to be done on parties from the antiestablishment centre, and inspires to examine the various populist and non-populist characteristics of their rhetoric within other discourses (beyond election campaigns and social media).

Evidence that not all populist parties are to be found on radical positional fringes, or that some parties do not link their disdain for the establishment with other elements of populism may dispel some concerns about the emergence of an ideologically-coherent populist juggernaut, but for those concerned about the stability of party systems and democracy, such findings are not particularly comforting. The threat posed by anti-establishment parties is not immediate or universal - indeed some of these parties can be quite useful in breaking up real political monopolies, restoring competitiveness, or empowering an inclusionary civic agency but anti-establishment parties may create problems of their own. When elected, some of these political challengers remain aloof and refuse to become part of governments that they themselves do not control; others head immediately for the most lucrative potential sources of 
revenue in government. Many of them, furthermore, do not make it to the next election, creating a hole that is often filled by an even newer, and even more intensely anti-establishment party, enhancing the stability of instability within CEE party systems (Haughton and Deegan Krause 2015). Concurrently, even established parties can in some circumstances successfully make use of anti-establishment tools, doubting the legitimacy of politics as a whole as a way to undercut their adversaries in rival political parties and in independent state institutions. When parties such as Hungary's Fidesz and Poland's PiS succeed in combining their existing organizational strength and entrenched position in the middle of the party system with anti-establishment appeals, nativism, and a self-image as the agent of the general will, the political dominance of such actors makes the threat of democratic backsliding quite tangible (Pytlas 2018).

In a world of increasing distrust of leaders, segmented communications channels, easyto-build institutional structures, and premiums for those who can construct and forge crises, these patterns do not seem likely to disappear any time soon. Exploring this multi-layered diversity of anti-establishment and populist politics hence provides both a challenging task for further research and a chance to provide a better understand the mechanisms of political mobilization and entrepreneurial strategies linked to this political agency.

\section{References}

Aalberg, Toril, Frank Esser, Carsten Reinemann, Jesper Strömbäck, and Claes de Vreese (eds.) (2016). Populist Political Communication in Europe. New York: Routledge.

ANO (23.09.2013). 'Předvolební Partie: Jana Bobošíková - Andrej Babiš', "anobudelip" Facebook Status. https://www.facebook.com/anobudelip/posts/527342274002677. Last access: 17 May 2018.

ANO (23.10.2013). 'Desatero pro vyšší zaměstnanost', "anobudelip" Facebook Status Update. https://www.facebook.com/anobudelip/posts/542760512460853. Last access: 17 May 2018. 
Arzheimer, Kai (2015). 'The AfD: Finally a Successful Right-Wing Populist Eurosceptic Party for Germany?', West European Politics, 38:3, 535-556.

Bakker, Ryan, Erica Edwards, Liesbet Hooghe, Seth Jolly, Gary Marks, Jonathan Polk, Jan Rovny, Marco Steenbergen, and Milada Vachudova. (2015a). 2014 Chapel Hill Expert Survey. Version 2015.1. Available on chesdata.eu. Chapel Hill, NC: University of North Carolina, Chapel Hill.

Bakker, Ryan, Catherine de Vries, Erica Edwards, Liesbet Hooghe, Seth Jolly, Gary Marks, Jonathan Polk, Jan Rovny, Marco Steenbergen, and Milada Vachudova (2015b). 'Measuring Party Positions in Europe: The Chapel Hill Expert Survey Trend File, 1999_ 2010.' Party Politics, 21(1): 143-152.

Bernhard, Laurent, and Hanspeter Kriesi (2018). 'Populism in Election Times: A

Comparative Analysis of Eleven Countries in Western Europe', West European Politics. doi:10.1080/01402382.2019.1596694

Budge, Ian, Hans-Dieter Klingemann, Andrea Volkens, and Judith Bara (2001). Mapping Policy Preferences. Estimates for Parties, Electors, and Governments 1945-1998. Oxford: Oxford University Press.

Caiani, Manuela, and Linda Parenti (2013). European and American Extreme Right Groups and the Internet. Farnham: Ashgate.

Caiani, Manuela, and Paolo R. Graziano (2016). 'Varieties of Populism. Insights from the Italian Case', Italian Political Science Review, 46:2, 243-267.

Canovan, Margaret (2002). 'Taking Politics to the People: Populism as the Ideology of Democracy', in Yves Mény and Yves Surel (eds.), Democracies and the Populist Challenge. New York: Palgrave, 25-44.

Caramani, Daniele (2017). 'Will vs. Reason: The Populist and Technocratic Forms of Political Representation and Their Critique to Party Government', American Political Science Review, 111:1, 54-67. 
Deegan-Krause, Kevin, and Tim Haughton (2009). 'Toward a More Useful Conceptualization of Populism: Types and Degrees of Populist Appeals in the Case of Slovakia', Politics \& Policy, 37:4, 821-841.

Engler, Sarah (2016). 'Corruption and Electoral Support for New Political Parties in Central and Eastern Europe', West European Politics, 39:2, 278-304.

Engler, Sarah, Klaus Armingeon, and Kevin Deegan-Krause. Forthcoming. Expert Survey on Party Claims on Corruption and Anti-Establishment Rhetoric. Bern/Detroit: University of Bern and Wayne State University.

Gerbaudo, Paolo (2014). 'Populism 2.0: Social Media Activism, the Generic Internet User and Interactive Direct Democracy', in Daniel Trottier and Christian Fuchs (eds.), Social Media, Politics and the State: Protests, Revolutions, Riots, Crime and Policing in the Age of Facebook, Twitter and YouTube. Abingdon: Routledge, 67-87.

Hanley, Seán, and Allan Sikk (2016). 'Economy, Corruption or Floating Voters? Explaining the Breakthroughs of Anti-establishment Reform Parties in Eastern Europe', Party Politics, 22:4, 522-533.

Haughton, Tim, and Kevin Deegan-Krause (2015). 'Hurricane Season: Systems of Instability in Central and East European Party Politics', East European Politics and Societies and Cultures, 29:1, 61-80.

Hawkins, Kirk A. (2009). 'Is Chávez Populist? Measuring Populist Discourse in Comparative Perspective', Comparative Political Studies, 42:8, 1040-1067.

Jagers, Jan, and Stefaan Walgrave (2007). 'Populism as Political Communication Style. An Empirical Study of Political Parties' Discourse in Belgium', European Journal of Political Research, 46:3, 319-345.

Lisi, Marco, Iván Llamazares, and Myrto Tsakatika (2018). 'Economic Crisis and the Variety of Populist Response: Evidence from Greece, Portugal and Spain', West European Politics. doi:10.1080/01402382.2019.1596695. 
Kitschelt, Herbert (1992).' The Formation of Party Systems in East Central Europe', Politics Society, 20(1), 7-50.

Kleinnijenhuis, Jan, and Paul Pennings (2001). 'Measurement of Party Positions on the Basis of Party Programmes, Media Coverage and Voter Perceptions', in Michael Laver (ed.), Estimating the policy position of political actors. London: Routledge, 162-182.

Klingemann, Hans-Dieter, Andrea Volkens, Judith Bara, Ian Budge, and Michael McDonald (2006). Mapping Policy Preferences II. Estimates for Parties, Electors, and Governments in Eastern Europe, the European Union and the OECD, 1990-2003. Oxford: Oxford University Press.

Kopeček, Lubomír (2016). “'I'm Paying, So I Decide”: Czech ANO as an Extreme Form of a Business-Firm Party', East European Politics and Societies, 30:4, 725-749.

Kornai, János (2006). 'The Great transformation of Central Eastern Europe. Success and Disappointment', Economics of Transition, 14:2, 207-244.

Korwin-Mikke, Janusz (2012). ‘Korwin-Mikke: Jakie są zalety D***kracji?’, Najwyższy Czas!, 05. November. http://nczas.com/publicystyka/korwin-mikke-jakie-sa-zaletydemokracji/. Last access: 22. October 2017.

Kriesi, Hanspeter, und Takis S. Pappas (2015). 'Populism in Europe During Crisis: An Introduction', in Hanspeter Kriesi and Taskis S. Pappas (eds.), Populism in the Shadow of the Great Recession. Colchester: ECPR Press.

Kuckartz, Udo (2007). Einführung in die computergestützte Analyse qualitativer Daten. Wiesbaden: VS Verlag für Sozialwissenschaften.

Kukiz'15 (16.09.2015). 'Ponieważ wiele osób pyta o stanowisko Ruchu Kukiz'15 w sprawie "uchodźców", 'Kukiz'15' Facebook Status. https://www.facebook.com/KlubPoselskiKukiz15/posts/403989849803272. Last access: 17.05.2018. 
Kukiz, Paweł (29.07.2015). 'Co chwilę słychać obietnice', "Paweł Kukiz" Facebook Status. https://www.facebook.com/kukizpawel/posts/931919130209141. Last access: 17. May 2018

Kukiz, Paweł (07.10.2015). 'Trzy filary naszej strategii', "Paweł Kukiz" Facebook Status. https://www.facebook.com/kukizpawel/posts/968487579885629. Last access: 17 May 2018.

March, Luke (2007). 'From Vanguard of the Proletariat to Vox Populi: Left-Populism as a “Shadow” Of Contemporary Socialism', SAIS Review of International Affairs, 27(1), 6377.

March, Luke (2017). 'Left and Right Populism Compared. The British Case', British Journal of Politics and International Relations, 19:2, 282-303.

March, Luke, and Daniel Keith (2016). Europe's Radical Left. From Marginality to the Mainstream? Lanham: Rowman \& Littlefield.

Marks, Gary, Liesbet Hooghe, Moira Nelson, and Erica Edwards (2006). 'Party Competition and European Integration in the East and West: Different Structures, Same Causality', Comparative Political Studies, 39:2, 155-175.

Minkenberg, Michael, ed. (2015). Transforming the Transformation? The East European Radical Right in the Political Process. Abingdon: Routledge.

Moffitt, Benjamin (2016). The Global Rise of Populism. Palo Alto: Stanford University Press. Mosca, Lorenzo, and Filippo Tronconi (2018). Beyond Left and Right: The Eclectic Populism of the Five Star Movement, West European Politics. doi: 10.1080/01402382.2019.1596691 Mudde, Cas (2004). 'The Populist Zeitgeist', Government and Opposition, 39:4, 541-63. Mudde, Cas (2007). Populist Right Parties in Europe. Cambridge: Cambridge University Press. Mudde, Cas, and Cristóbal Rovira Kaltwasser (2013). 'Exclusionary vs. Inclusionary Populism. Comparing Contemporary Europe and Latin America', Government and Opposition, $48: 2,147-174$. 
Mudde, Cas and Cristóbal Rovira Kaltwasser (2017). Populism. A Very Short Introduction. New York: Oxford University Press.

Okamura, Tomio (24.10.2013). 'Po internetu někdo začal o našem hnutí Úsvit př́mé demokracie šiřit lživou fámu', "tomio.cz" Facebook Status. https://www.facebook.com/tomio.cz/photos/a.185333081477515.45875.179497582061065/691 452664198885/?type=3. Last viewed: 17.05.2018.

Okamura, Tomio (25.10.2013). 'Dnes a zítra budeme moci rozhodnout o osudu naší země', "tomio.cz" Facebook Status. https://www.facebook.com/tomio.cz/posts/691851004159051. Last access: 17 May 2018.

Pirro, Andrea L. (2015). The Populist Radical Right in Central and Eastern Europe. Ideology, Impact, and Electoral Performance. Abingdon: Routledge.

Pop-Eleches, Grigore (2008). 'A party for All Seasons: Electoral Adaptation of Romanian Communist Successor Parties', Communist and Post-Communist Studies, 41:4, 465-479. Pop-Eleches, Grigore (2010). 'Throwing out the Bums. Protest Voting and Unorthodox Parties after Communism', World Politics, 62:2, 221-260.

Pytlas, Bartek (2013). 'Radical-right Narratives in Slovakia and Hungary: Historical Legacies, Mythic Overlaying and Contemporary Politics', Patterns of Prejudice, 47:2, 162-183.

Pytlas, Bartek (2015). Radical Right Parties in Central and Eastern Europe. Mainstream Party Competition and Electoral Fortune. Abingdon: Routledge.

Pytlas, Bartek (2018). 'Populist Radical Right Mainstreaming and Challenges to Democracy in an Enlarged Europe', in Lise E. Herman and James Muldoon (eds.), Trumping the Mainstream: The Conquest of Democratic Politics by the Populist Radical Right. Abingdon: Routledge.

Pytlas, Bartek. Forthcoming. Qualitative Content Analysis Dataset on Anti-Establishment Strategies in Europe. Munich: LMU Munich. 
Pytlas, Bartek, and Oliver Kossack (2015). 'Lighting the Fuse: the Impact of Radical Right Parties on Party Competition in Central and Eastern Europe', in Michael Minkenberg (ed.), Transforming the Transformation? The East European Radical Right in the Political Process. Abingdon: Routledge, 105-36.

Razem (13.08.2015). 'Realną kontrolę nad polityką obywatele mogą sprawować', "partiarazem" Facebook

Status. https://www.facebook.com/partiarazem/posts/495809227253805. Last access: 17 May 2018.

Rohrschneider, Robert, und Stephen Whitefield. (2009). 'Understanding Cleavages in Party Systems. Issue Position and Issue Salience in 13 Post-Communist Democracies', Comparative Political Studies, 42:2, 280-313.

Rooduijn, Matthijs, and Teun Pauwels (2011). 'Measuring Populism. Comparing Two Methods of Content Analysis', West European Politics, 34:6, 1272-1283.

Rydgren, Jens (2017). 'Radical Right-wing Parties in Europe. What's Populism Got to Do With It?', Journal of Language and Politics, 16:4, 485-496.

Sartori, Giovanni (1970). 'Concept Misinformation in Comparative Politics', American Political Science Review, 64:4, 1033-1053.

Sikk, Allan (2009). 'Parties and Populism'. Centre for European Politics, Security \& Integration Working Paper 2009-02.

Sme Rodina (08.02.2016). 'Predstavujeme Vám d'alšiu kandidátku hnutia SME RODINA', " HnutieSmeRodina" Facebook Status. https://www.facebook.com/HnutieSmeRodina/photos/a.600284246776090.107374182 8.600235073447674/629724853832029/?type=3\&theater. Last access: 17 May 2018 Sme Rodina (2016). 'S úctou Vaša kandidátka Luba Marková', " HnutieSmeRodina" Facebook Status. 
https://www.facebook.com/HnutieSmeRodina/photos/a.600284246776090.107374182 8.600235073447674/635537299917451/?type=3. Last access: 17 May 2018.

Szczerbiak, Aleks (2007). “'Social Poland” Defeats 'Liberal Poland'? The September-October 2005 Polish Parliamentary and Presidential Elections', Journal of Communist Studies and Transition Politics, 23:2, 203-232.

Učeň, Peter (2007). 'Parties, Populism, and Anti-Establishment Politics in East Central Europe', SAIS Review, 27:1, 49-62.

Vachudova, Milada (2008). 'Centre-Right Parties and Political Outcomes in East Central Europe', Party Politics, 14:4, 387-405. 
${ }^{1}$ For the sake of convenience, we will only use the term 'anti-establishment rhetoric' in the sections that follow. The wording of the question we asked (retrospectively) to all country experts was as follows: 'We would like you to consider the salience (i.e. importance) of the following issues for Party $X$ in the electoral campaign of the national parliamentary elections between YYYY and YYYY": salience of anti-elite and anti-establishment rhetoric (0 not important at all; 10 extremely important)'. According to our understanding, anti-elite and anti-establishment rhetoric does not differ substantially and both can include the political establishment/elite as well as other types of dominant groups in the society (such as the economic elite, intellectual elite etc.) However, we are aware that there is the possibility that these two terms might not be considered as interchangeable by everyone. The reasons to include both terms in the questions have been twofold: First, it allows a direct comparison with the data of the Chapel Hill Expert Survey that uses the same wording ( $r=0.89)$ and second, including both terms minimizes the risk that claims against the elite or the establishment are not reported. In addition, we have provided a definition to all experts in order to secure that they have a common understanding of the question: 'Those engaging in anti-establishment rhetoric explicitly identify with 'ordinary people' and contrast themselves against a separate and coherent 'political class' that is composed of all political opponents undifferentiated by party affiliation and may also (but need not) include economic, intellectual and/or international elites.'

${ }^{2}$ Since the survey is conducted retrospectively, for each party of each election we asked the following question:

'Now, we would like you to self-assess your judgement in the last two questions. How confident are you of your responses on [party] for each election?' (1 very uncertain; 4 very confident). We excluded answers that are too uncertain to consider (responses with a confidence level lower than 3).

${ }^{3}$ The data on anti-establishment rhetoric has been combined with the Chapel Hill version using the version that follows an election, i.e. 2009 and 2010 elections: 2010 data; 2011-2014 elections: 2014 data.

${ }^{4}$ Government participation can be a reason for the reduction of anti-establishment rhetoric that might in some cases lead to the transformation of an AEP to a non-AEP (as it is the case for GERB and 
Fidesz between 2009 and 2014). However, as the cases of governing parties among AEPs (SNS in 2010, SaS in 2012 and NA in 2010) and the numerous opposition parties among the non-AEPs illustrate, the government-opposition pattern is not the main determinant of the classification into AEP/non-AEP. Moreover, when looking at the patterns over time, the differences between AEPs and non-AEPs are usually larger than the changes of a single party over time (see Figure A1 and A2 for an illustration of Poland and Slovakia). For example, while PiS had indeed its lowest value of antiestablishment rhetoric while in government in 2007 (7.6), the value is still much higher than the values of PO while in opposition (never higher than 6.4). The same is true for SNS in Slovakia. It had its lowest salience while in government (2012: 3.7); but this was still higher than the highest salience among non-AEPs, even while in opposition (2.2). Smer is an exception, since it has clearly transformed from an AEP (former centrist populist, see Učeň 2007) with a high salience of antiestablishment rhetoric during its first two terms in opposition into a non-AEP since 2010. It had a slightly higher anti-establishment salience than the average in opposition in 2012, that was, however, still low in absolute terms.

${ }^{5}$ The populist radical right is defined as combination of populism with nativism and authoritarianism (Mudde 2007). The definition thus includes these elements of the cultural dimension, while the economic position can vary. Academic debate on definitional standards for the populist radical left in Western Europe are much scarcer, however, parties are usually considered as populist radical left when they combine economic leftist stances with populist elements (March 2007, 2017, see also Bernard and Kriesi in this issue). For AEPs with strong neoliberal and/or strong libertarian stances there is no common term.

${ }^{6}$ The ideological mainstream is defined as the opposite of radical left (i.e. no extreme leftist position on the economic dimension) and the opposite of the radical right (i.e. no extreme traditionalist/authoritarian/nationalist position on the cultural dimension; Hanley and Sikk, 2016: 523). ${ }^{7}$ It is important to mention that those parties are usually new parties that often transform ideologically and/or abandon their anti-establishment discourse over time and thereby cease to be a centrist populist party. See for example GERB in Figure 4 that does not transform ideologically, but in 2014, belongs to the group of non-AEPs. This is important when it comes to the case selection for the second part of 
the analysis that focuses on the most recent election up to 2016 (e.g. Slovakia 2016, Poland 2015 and Czech Republic 2013). By the time of these latter elections, two former centrist AEP parties, Smer and Your Movement (formerly Palikot's Movement), had reduced their anti-establishment salience to a point below the election-wide average and therefore are not included in the sample of AEPs (see Appendix, Figure A1 and Figure A2).

${ }^{8}$ Data on challengers that did not cross the electoral threshold (Razem, KORWiN) or those that entered national parliaments unexpectedly (SR, LSNS) are missing in the expert survey. For these actors, anti-establishment salience was estimated by a holistic analysis of electoral manifestos, as well as campaign events reported in traditional media.

${ }^{9}$ In two cases in Poland, social media profiles of party leaders (Janusz Korwin-Mikke, currently leading the extra-parliamentary party Freedom of Janusz-Korwin Mikke; as well as Robert Winnicki of Ruch Narodowy) were coded instead of party profiles. Focusing on the person of Korwin-Mikke is due to his iconic status among the supporters of his personal vehicle parties, such as KORWiN. And allows a more rigorous analysis than the assessment of his ephemeral political projects. Coding the profile of Robert Winnicki on the other hand allows continuity following the deletion of Ruch Narodowy's Facebook profile. The claims of Winnicki can be seen as exemplary of RN discourse due to his central role as party leader and as the only remaining formal member of Ruch Narodowy in the Polish Parliament, after several members of RN elected to the Sejm from the Kukiz lists left the RN in May 2016. 